\title{
ZAKAT PROFESI DALAM ERA KONTEMPORER
}

\author{
A. INTAN CAHYANI \\ Universitas Islam Negeri Alauddin Makassar
}

\begin{abstract}
Professional zakat is issued from professional income when it reaches the nisab. In the case of professional zakat, the Indonesian Ulema Council regulates it in income zakat. The Indonesian Ulema Council has issued its fatwa with the "Decree of the Fatwa of the Indonesian Ulema Council" Number 3 of 2003 concerning Income Zakat. Although many scholars agree with the application of professional zakat in today's contemporary era, on the other hand there are those who don't approve of its application. They base the view that the issue of zakat is entirely an 'ubudiyah problem. So that all kinds of rules and regulations may only be carried out if there are clear and firm instructions or direct examples from the Prophet and if there are none, then there is no need to make new rules.
\end{abstract}

Keywords: Contemporary, Profession, Zakat.

\begin{abstract}
Abstrak
Zakat profesi adalah zakat yang dikeluarkan dari penghasilan profesi (hasil profesi/pekerjaan) bila telah mencapai nisab. Terhadap kasus zakat profesi, Majelis Ulama Indonesia (MUI) mengaturnya dalam zakat penghasilan. MUI telah mengeluarkan fatwanya dengan "Keputusan Fatwa Majelis Ulama Indonesia" Nomor 3 Tahun 2003 tentang Zakat Penghasilan. Walaupun banyak ulama yang sependapat dengan diberlakukannya zakat profesi di era kontemporer dewasa ini, namun di pihak lain ada pula yang tidak menyetujui pemberlakuannya. Mereka mendasarkan pandangan bahwa masalah zakat sepenuhnya masalah 'ubudiyah. Sehingga segala macam bentuk aturan dan ketentuannya hanya boleh dilakukan kalau ada petunjuk yang jelas dan tegas atau contoh langsung dari Rasulullah saw dan bila tidak ada, maka tidak perlu membuat-buat aturan baru.
\end{abstract}

Kata Kunci : Kontemporer, Profesi, Zakat.

\section{PENDAHULUAN}

Secara sosiologis, zakat adalah refleksi dari rasa kemanusiaan, keadilan, keimanan, dan ketaqwaan yang mendalam yang harus muncul dalam sikap orang kaya. Tidaklah etis sebagai seorang makhluk social mau hidup sendiri tanpa memperhatikan kesulitan orang lain. 
Zakat adalah ibadah mliyah ijtima'iyyah yang memiliki posisi yang sangat penting, strategis, dan menentukan, baik dari sisi ajaran maupun dari sisi pembangunan kesejahteraan ummat. ${ }^{1}$ Jadi, disamping merupakan ibadah yang berdimensi mahdhah, zakat juga berdimensi sosial.

Dalam sejarah perjalanan masyarakat Islam, ajaran Islam sudah mulai disempitkan dan dilupakan artinya, zakat seolah-olah hanya kewajiban individu dan dilaksanakan dalam rangka menggugurkan kewajiban individu terhadap perintah Allah, sehingga lupa kalau zakat sebenarnya juga bertujuan untuk membantu hamba Allah yang masih membutuhkan pertolongan. Hal ini disebabkan karena mundurnya peranan Islam di panggung politik, ekonomi, ilmu, dan peradaban.

Salah satu indikator dari kurangnya kesadaran umat muslim mengenai zakat tersebut, dapat dilihat dengan masih tingginya angka dan grafik kemiskinan di dunia Islam, khususnya di lingkungan umat Islam di Indonesia. Hal ini terjadi karena belum akuratnya pemahaman sebagian umat Islam tentang konsep zakat, baik pada konsep teoritik maupun pada konsep operasionalnya.

Secara teoritik, dalam fikih klasik dikenal ada dua jenis zakat yaitu zakat fitrah dan zakat harta. Kedua jenis zakat inilah yang selama ratusan tahun dipraktekkan oleh ummat muslim di seluruh dunia yang merujuk pada kitab-kitab fikih hasil ciptaan ulama terdahulu.

Terkait dengan jenis zakat harta di atas, di zaman moderen sekarang ini, dikenal sebuah wacana zakat profesi. Yaitu berupaya untuk mengembangkan jenis-jenis harta yang harus dikeluarkan zakatnya. Wacana zakat profesi tersebut merupakan ijtihad para ulama di masa kini yang nampaknya berangkat dari ijtihad yang cukup memiliki alasan dan dasar yang juga cukup kuat. Salah satu alasannya adalah rasa keadilan.

Wacana inilah yang kemudian menimbulkan pertanyaan di kalangan umat muslim sebab diketahui bahwa dewasa ini muncul berbagai jenis kasus yang tidak mempunyai kepastian hukum, sehingga umat muslim kebingungan dalam mengambil sikap tegas atas persoalan yang sedang mereka hadapi. Salah satu pertanyaan yang masih menggelayut dalam benak umat muslim adalah persoalan penghasilan dari profesi seseorang, apakah persoalan tersebut termasuk kategori yang harus dikeluarkan zakatnya atau tidak. Hal ini wajar saja terjadi sebab persoalan tersebut tidak ditemukan aturannya secara jelas dalam berbagai kitabkitab fikih klasik dari ulama-ulama terdahulu.

${ }^{1}$ Yusuf Qardhawi, al-Ibadah fi al-Islam (t.t., t.p., 1993), h. 235.

163 
Untuk itulah penulis kemudian tertarik untuk menulis ini sebagai bahan masukan dan bisa menjadi referensi bagi umat muslim yang membutuhkannya.

\section{METODE PENELITIAN}

Penelitian ini dilakukan berdasarkan studi pustaka dengan berbagai referensi jurnal dan buku serta beberapa artikel terbaik dan terupdate. Penelitian Pustaka (library research) yaitu Penelitian dilaksanakan dengan mengumpulkan data dan landasan teoritis dengan mempelajari buku, karya ilmiah, hasil penelitian terdahulu, jurnal-jurnal terkait, artikel-artikel yang terkait serta sumber-sumber yang terkait dengan penelitian sesuai dengan penelitian yang diteliti. Setelah semua data telah diperoleh berhasil dikumpulkan selama proses penelitian baik data primer dan data sekunder dianalisis secara kualitatif kemudian disajikan secara deskriptif yaitu menjelaskan, menguraikan, menggambarakan permasalahan yang berkaitan dengan zakar profesi dalam era kontemporer.

\section{PEMBAHASAN}

\section{A. Kontemporernya Zakat Profesi}

Profesi/pekerjaan adalah merupakan salah satu bagian dari beragam hal yang mendatangkan penghasilan. Hal ini sebagaimana yang dapat ditemukan dalam defenisi income (penghasilan), ialah: periodic (usually annual) receips from one's business, lands, works, investments, etc., artinya: penerimaan-penerimaan yang diperoleh dari hasil, bisnis, tanah, pekerjaan/pofesi, investasi, dan sebagainya dalam waktu tertentu (biasanya dihitung pertahun). ${ }^{2}$ Jadi, berdasar pada defenisi tersebut di atas, maka dapatlah dipahami bahwa profesi hanyalah merupakan salah satu bagian dari berbagai jenis bentuk-bxentuk yang mendatangkan penghasilan dan mesti dikeluarkan zakatnya.

Sedangkan zakat profesi adalah zakat yang dikeluarkan dari penghasilan profesi (hasil profesi/pekerjaan) bila telah mencapai nisab. Profesi dimaksud mencakup profesi Pegawai Negeri Sipil atau swasta, konsultan, dokter, notaris, akuntan, artis, wiraswasta, dll. ${ }^{3}$

Barangkali bentuk penghasilan yang paling menyolok pada zaman sekarang ini adalah apa yang diperoleh dari pekerjaan dan profesinya. Pekerjaan yang menghasilkan uang ada dua macam. Pertama adalah pekerjaan yang dikerjakan sendiri tanpa tergantung kepada orang lain, berkat kecekatan tangan

${ }^{2}$ H.W. Fowler dan F.G. Fowler, The Concise Oxford Dictionary of Current English (London: Oxford, 1952), h. 603.

${ }^{3}$ Panduan Zakat Profesi, dalam http://www.pkpu.or.id/Panduan.php?id=3, diakses tanggal 12 April 2009. 
ataupun otak. Penghasilan yang diperoleh dengan cara ini merupakan penghasilan profesional, seperti penghasilan seorang dokter, insinyur, advokat, seniman, penjahit, tukang kayu dan lain-lainnya. Yang kedua, adalah pekerjaan yang dikerjakan seseorang buat pihak lain baik pemerintah, perusahaan, maupun perorangan dengan memperoleh upah, yang diberikan, dengan tangan, otak, ataupun kedua-duanya. Penghasilan dari pekerjaan seperti itu berupa gaji, upah, ataupun honorarium. ${ }^{4}$

Harus diingat bahwa meski di zaman Rosulullah saw. telah ada beragam profesi, namun kondisinya berbeda dengan zaman sekarang dari segi penghasilan. Di zaman itu penghasilan yang cukup besar dan dapat membuat seseorang menjadi kaya berbeda dengan zaman sekarang. Diantaranya adalah berdagang, bertani, dan berternak. Sebaliknya, di zaman sekarang ini berdagang tidak otomatis membuat pelakunya menjadi kaya, sebagaimana juga bertani dan berternak. Bahkan umumnya petani dan peternak di negeri kita ini termasuk kelompok orang miskin yang hidupnya masih kekurangan.

Sebaliknya, profesi-profesi tertentu yang dahulu sudah ada, tapi dari sisi pendapatan saat itu tidaklah merupakan kerja yang mendatangkan materi besar. Di zaman sekarang ini justru profesi-profesi inilah yang mendatangkan sejumlah besar harta dalam waktu yang singkat. Seperti Dokter Spesialis, Arsitek, Komputer Programer, Pengacara, dan sebagainya. Nilainya bisa ratusan kali lipat dari petani dan peternak miskin di desa-desa. ${ }^{5}$ Namun profesi tersebut masih dalam bentuk yang sangat sederhana.

Perubahan Sosial inilah yang mendasari ijtihad para ulama hari ini untuk melihat kembali cara pandang kita dalam menentukan : siapakah orang kaya dan siapakah orang miskin, intinya zakat itu adalah mengumpulkan harta orang kaya untuk diberikan pada orang miskin. Di zaman dahulu, orang kaya identik dengan Pedagang, Petani, dan Peternak. Tapi di zaman sekarang ini, orang kaya adalah para profesional yang bergaji besar. Zaman berubah namun prinsip zakat tidak berubah. Yang berubah adalah realitas di masyarakat. Tapi intinya orang kaya menyisihkan uangnya untuk orang miskin. Dan itu adalah intisari zakat.

\footnotetext{
${ }^{4}$ Zakat menurut Pandangan Yusuf Qardhawi, dalam http://media.isnet.org/islam/Qardhawi/Zakat/Profesi/01.html\#Pandangan, diakses tanggal 12 April 2009.

${ }^{5}$ Zakat Profesi Wajib Atau Tidak, dalam http:///naqsh abandibatam.org/keagamaan/artikel/message-dan tulisan-Islam/zakat-profesi-wajib-atau-tidak.html, diakses tanggal 12 Apri 2009.
}

165 
Dengan demikian, zakat profesi merupakan ijtihad pada ulama di masa kini yang nampaknya berangkat dari ijtihad yang cukup memiliki alasan dan dasar yang juga cukup kuat. Akan tetapi tidak semua ulama sepakat dengan hal tersebut.

Kemungkinan tersebut bisa saja terjadi sebab sebagaimana yang dipahami dalam kaedah ushul fikih bahwa: ${ }^{6}$

$$
\text { تغيرالفتوى واختلا فها بحسب تغير الازمن والاحوال والامكان والعوئد والنية }
$$

Artinya:

Hukum akan berubah seiring dengan berubahnya waktu, keadaan, tempat, adat istiadat, dan juga niat.

Berdasarkan pada kaedah ushul fikih tersebut, sehingga menjadi suatu hal yang mungkin terjadi ketika persoalan zakat profesi tersebut muncul ke permukaan menjadi sebuah wacana untuk kemudian didiskusikan bersama. Meskipun kiranya masalah zakat profesi tidak sedikitpun disinggung dalam berbagai kitab-kitab fikih klasik oleh ulama-ulama terdahulu.

Hal ini menjadi mungkin lagi sebab persoalan zakat tersebut maliyah ijtima'iyyah yang memang Allah swt. memberi peluang yang seluas-luasnya kepada umat muslim untuk berijtihad karena tergolong persoalan mu'amalat selama tetap berpegang teguh pada prinsip-prinsip ajaran Islam yang telah ditentukan.

\section{B. Pandangan Hukum Islam Mengenai Zakat Profesi}

Terkait dengan pandangan hukum Islam, setidaknya ada empat produk pemikiran hukum Islam yang ada di Indonesia yang dapat meninjau eksistensi zakat profesi. Keempat produk pemikiran hukum Islam tersebut adalah, fatwa, fikih, keputusan Pengadilan/yurisprudensi, dan Undang-Undang. ${ }^{7}$ t.th.), h. 3.

${ }^{6}$ Ibn Qayyim al-Jauziyyah, I'Im al-Muw $\pm q i^{\prime}$ in 'an Rabb al-'2lam ${ }^{3} n$ (Juz III, Beirut: Dr al-Jail,

7 UU yaitu peraturan yang dibuat oleh suatu badan legislative yang mengikat kepada setiap warga Negara dimana UU itu diberlakukan, yang apabila dilanggar akan dikenakan sanksi. Fatwa adalah suatu jawaban resmi terhadap (a) pertanyaan atau (b) persoalan penting menyangkut dogma atau hokum, yang diberikan oleh seseorang/lembaga yang mempunyai otoritas untuk melakukannya. Merupakan keputusan hakim di Pengadilan berdasarkan pemeriksaan perkara di depan persidangan. Ahmad Rofiq, Hukum Islam di Indonesia, cet. I (Jakarta: Rajawali Press, 2007), h. 8-9. Lihat pula: MB. Hooker, Islam Mazhab Indonesia: FatwaFatwa dan Perubahan Sosial (Jakarta: Teraju, 2002), h. 21.

166 
Untuk kasus zakat profesi, akan dicoba untuk ditinjau dari tiga produk pemikiran hukum Islam di atas. Ketiganya itu adalah fikih (yang dalam hal ini pandangan ulama kontemporer), Fatwa ulama (MUI), dan Undang-Undang (UU no. 38 tahun 1999 tentang pengelolaan zakat).

\section{Fatwa Ulama}

Terhadap kasus zakat profesi, Majelis Ulama Indonesia (MUI) mengaturnya dalam zakat penghasilan. MUI telah mengeluarkan fatwanya dengan "Keputusan Fatwa Majelis Ulama Indonesia” Nomor 3 Tahun 2003 tentang Zakat Penghasilan. Adapun penetapannya dilakukan di Jakarta pada tanggal 7 Juni $2002 \mathrm{M}$ bertepatan dengan tanggal 6 Rabiul Akhir $1423 \mathrm{H}^{8}{ }^{8}$ Meskipun sebagian kecil masyarakat masih mempertanyakan legalitas zakat profesi tersebut. Mereka yang menentang penerapan syariat zakat profesi ini beranggapan bahwa zakat profesi tidak pernah dikenal sebelumnya di dalam syariat Islam dan merupakan hal baru yang diada-adakan. ${ }^{9}$

Adapun keputusan yang telah diambil oleh MUI dalam hal ini terdapat dalam empat poin, yaitu:

Pertama, dalam poin ini MUI menetapkan apa yang menjadi defenisi dari penghasilan yang akhirnya di keluarkan dalam bentuk zakat profesi tersebut, menyatakan bahwa yang dimaksud dengan "penghasilan" adalah setiap pendapatan seperti gaji, honorarium, upah, jasa, dan lain-lain yang diperoleh dengan cara halal, baik rutin maupun tidak rutin seperti dokter, pengacara, konsultan, dan sejenisnya, serta pendapatan yang diperoleh dari pekerjaan bebas lainnya. Kedua, yang menjadi hukum dari zakat profesi tersebut adalah semua bentuk penghasilan halal wajib dikeluarkan zakatnya dengan syarat telah mencapai nishab dalam satu tahun, yakni senilai emas 85 gram. Ketiga, terkait dengan waktu mengeluarkan zakat. Dalam hal ini MUI membuat dua ketetapan untuk berzakat: 1) Dikeluarkan pada saat menerima penghasilan, jika penghasilan yang diterima tersebut sudah cukup nishab. 2) Jika tidak mencapai nishab, maka semua penghasilan dikumpulkan dalam satu tahun; kemudian zakat dikeluarkan jika penghasilan bersihnya sudah cukup nishab. Keempat,

\footnotetext{
${ }^{8}$ Lihat: Departemen Agama RI, Himpunan Fatwa MUI (Jakarta: DIRJEN BIMAS Islam \& Penyelenggaraan Haji DEPAG RI, 2003), h. 87-91.

${ }^{9}$ Istilah zakat profesi adalah baru, sebelumnya tidak pernah ada seorang ulamapun yang mengungkapkan dari dahulu hingga saat ini, kecuali Syaikh Yusuf Qaradhowy menuliskan masalah ini dalam kitab Zakat-nya, kemudian di taklid (diikuti tanpa mengkaji kembali kepada nash yang syar'i) oleh para pendukungnya, termasuk di Indonesia ini. Lihat: Seputar Zakat Profesi, dalam http://www. pesantren virtual.com/index.php/seputar-zakat/1180-zakat-profesi, diakses tangga 12 April 2009. Bandingkan pula dengan: Zakat Profesi, adakah?, dalam http://aliph.wordpress.com/2007/02/08/zakat-profesi-adakah/, diakses tanggal 12 April 2009.
} 
terkait dengan kadar zakatnya. Kadar zakat penghasilan yang ditetapkan oleh MUI adalah sebesar 2,5\%. ${ }^{10}$

Dari keempat poin tersebut di atas, tampak MUI sangat serius dalam menyikapi permintaan masyarakat luas dan juga Badan Amil Zakat Nasional (BAZNAS) yang meminta fatwa terkait dengan zakat profesi tersebut. Sehingga berdasar pada ketentuan yang berkewajiban mengeluarkan zakat, dapat diketahui jika siapapun yang memiliki penghasilan yang sudah mencapai nishab dan haulnya, baik itu PNS, dokter, pengacara, konsultan, dll., wajib mengeluarkan 2,5\% dari keseluruhan penghasilannya.

Fatwa MUI yang mewajibkan zakat profesi tersebut sejalan dengan beberapa dalil syar'i yang merupakan landasan normatif pelaksanaan zakat, yaitu:

1. Firman Allah dalam QS. al-Baqarah: 267.

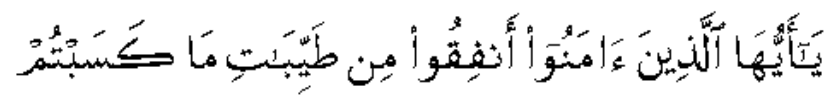

Terjemahannya:

Hai orang-orang yang beriman, nafkahkanlah (di jalan Allah) sebagian dari hasil usahamu yang baik-baik...

Demikian juga dalam QS. Al-Taubah: 60.

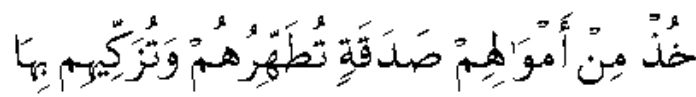

Terjemahannya:

Ambillah zakat dari sebagian harta mereka, dengan zakat itu kamu membersihkan dan mensucikan mereka...

Dari dua ayat tersebut di atas, tampak jelas bagaimana Majelis Ulama Indonesia berdasar pada ungkapan ayat di atas yang menggunakan bentuk fi'il amr ( انفقو ا خد dan ), sehingga dapat dipahami bahwa Allah swt. memerintahkan ummatnya untuk menyisihkan sebagian dari hartanya untuk dizakatkan kepada mereka yang sangat menbutuhkannya.

Kata "ما" dalam QS. al-Baqarah: 267 di atas, adalah termasuk kata yang mengandung pengertian yang umum, yang artinya "apa saja". Jadi

${ }^{10}$ Departemen Agama RI, op.cit., h. 90-91. 
"كسبتمartinya "sebagian dari hasil (apa saja) yang kamu usahakan yang baikbaik". Maka jelaslah, berdasar pada apa yang tersirat dari ayat tersebut, mengisyaratkan untuk mengeluarkan zakat dari segala yang merupakan pendapatan umat muslim, dengan syarat jika sudah terpenuhi nishab dan haulnya.

Kiranya sangatlah mendasar sekiranya penghasilan dari hasil pekerjaan apapun jika memenuhi nishab dan haulnya agar dikeluarkan zakatnya. Sebab seiring dengan perubahan tempat dan waktu maka persoalan zakat tersebut bisa saja berubah. Jenis-jenis yang dizakatkan pada zaman kitab fikih tersebut dibuat belum menjadikan profesi sebagai jenis penghasilan yang harus dikeluarkan zakatnya. Hal itu disebabkan karena profesi tersebut belum bisa menjadikan seseorang menjadi kaya. Sedangkan pada zaman sekarang muncul beragam jenis profesi yang sangat memungkinkan untuk dizakatkan karena menghasilkan pendapatan yang berpuluh kali bahkan ribuan kali lebih besar dibandingkan dengan jenis-jenis yang dizakatkan lainnya.

2. Al-Hadis

ان رسول الله ص م قال ليس على المسلم فى عبده و لا فرسه فقال النووي هد الحديث اصل في ان اموال القنية لا زكاة فيها

Terjemahannya:

Dari Abu Hurairah ra., Rasulullah saw. bersabda: Tidak ada zakat atas orang muslim terhadap hamba sahaya dan kudanya. (HR. Muslim). Imam Nawawi berkata: "Hadis ini adalah dalil bahwa harta qinyah (harta yang digunakan untuk keperluan pemakaian, bukan untuk dikembangkan) tidak dikenakan zakat.

$$
\text { روي مرفو عا من حديث ابن عمر عن النبي ص م انه قال لا زكاة فى مال حتى يحول عليه الحول }
$$

Terjemahannya:

Diriwayatkan secara marfu' hadis Ibn Umar, dari Nabi saw. beliau berkata: "Tidak ada zakat pada harta sampai berputar satu tahun".

Dari hadis tersebut, tampak jika Rasulullah saw. sangat memperhatikan persoalan zakat. Mengingat zakat merupakan barometer akan keimanan seseorang baik itu secara vertikal, yaitu hubungannya dengan Allah swt. maupun secara horizontal, yaitu hubungannya dengan sesama manusia.

\section{Fikih Kontemporer}


Fatwa MUI terkait dengan keempat poin dari keputusan di atas itu didasarkan pada yang telah dikemukakan oleh salah seorang ulama fikih kontemporer, yaitu Yusuf Qardhawi.

Pandangan Yusuf Qardhawi yang terkait dengan hukum zakat profesi/penghasilan itu didasarkan pada pendapat yang dikemukakan oleh Muhammad Ghazali dalam bukunya Islam wa al-Audza' al-Iqtishadiyyah. Lebih dari dua puluh tahun yang lalu. Ghazali menyebutkan bahwa dasar penetapan zakat dalam Islam hanyalah modal, bertambah, berkurang atau tetap, setelah lewat setahun, seperti zakat uang, dan perdagangan yang zakatnya seperempat puluh, atau atas dasar ukuran penghasilan tanpa melihat modalnya seperti zakat pertanian dan buah-buahan yang zakatnya sepersepuluh atau seperdua puluh, maka Ghazali mengatakan: "Dari sini kita mengambil kesimpulan, bahwa siapa yang mempunyai pendapatan tidak kurang dari pendapatan seorang petani yang wajib zakat, maka ia wajib mengeluarkan zakat yang sama dengan zakat petani tersebut, tanpa mempertimbangkan sama sekali keadaan modal dan persyaratan-persyaratannya. Berdasarkan hal itu, seorang dokter, advokat, pengusaha, pekerja, karyawan, pegawai, dan sebangsanya, wajib mengeluarkan zakat dari pendapatannya yang besar. ${ }^{11}$

Pandangan tersebut sangat sejalan dengan firman Allah swt. yang terdapat dalam QS. al-Baqarah: 267 yang menganjurkan untuk mengeluarkan sebagian dari hasil usaha yang halal untuk diberikan kepada mereka yang masih sangat membutuhkannya. Sehingga dari sini, tampaklah bahwa zakat itu juga mempunyai fungsi sosial disamping merupakan ibadhah mahdhah.

Selanjutnya yang berkaitan dengan nishab zakat profesi, bahwa nishab 85 gram emas yang menjadi ukuran minimal yang harus dikeluarkan zakatnya itu didasarkan pada kesamaan dua puluh misqal hasil pertanian yang disebutkan oleh banyak hadis. Sehingga, karena banyak orang yang memperoleh gaji dan pendapatan dalam bentuk uang, maka yang paling baik adalah menetapkan nishab gaji itu berdasarkan nishab uang. ${ }^{12}$ Berdasar pada pandangan Yusuf Qardawi tersebut, tampak jika Yusuf Qardawi mencoba berdasar pada nishab zakat tanaman dan buah-buahan yang dikeluarkan zakatnya setiap habis panen, tetapi karena yang menjadi obyek zakat adalah uang (berupa gaji/honorarium atau penghasilan lainnya), maka Yusuf Qardawi berijtihad dengan

\footnotetext{
${ }^{11}$ Yusuf Qardawi, Figh $a z-Z a k \pm t$, diterjemahkan oleh Salman Harun, Didi Hafidhuddin, dan Hasanuddin, dalam Hukum zakat: Studi Komparatif Mengenai Status dan filsafat Zakat Berdasarkan Qur'an dan Hadis, cet. IV (Jakarta: Mizan, 1996),h. 480.
}

${ }^{12}$ Ibid., h. 482. 
menggunakan nishab uang yang ukurannya telah ada sebelumnya yaitu sebesar 85 gram emas.

Adapun mengenai waktu pengeluaran zakat yang terdapat pada fatwa tersebut di atas, oleh Yusuf Qardhawi didasarkan pada kenyataan bahwa orangorang yang memiliki profesi itu memperoleh dan menerima pendapatan mereka tidak teratur, kadang-kadang setiap hari seperti pendapatan seorang dokter, kadang-kadang pada saat-saat tertentu seperti advokat dan kontraktor serta penjahit atau sejenisnya. Sebagian pekerja menerima upah mereka setiap minggu atau dua minggu, dan kebanyakan pegawai menerima gaji mereka setiap bulan. Sehingga keputusan yang diambil tergantung pada cukup tidaknya nishab dari pendapatan yang diterima serta sudah bersih dari hutang dan lebih dari kebutuhan pokok. ${ }^{13}$

Pada dasarnya penetapan syarat/ketentuan harta yang harus dikeluarkan zakatnya tersebut adalah untuk memperjelas mereka-mereka yang tergolong orang kaya dan wajib berzakat (muzakki) dan mereka yang tergolong orang miskin dan berhak menerima zakat (mustahik). Dari sini maka menjadi jelaslah apa yang menjadi tujuan disyari'atkannya zakat yaitu untuk membersihkan hati/harta orang-orang kaya, serta untuk meningkatkan kesejahteraan orang-orang yang tidak mampu.

Selanjutnya, adapun yang menjadi dasar penetapan jumlah 2,5\% yang harus dikeluarkan zakatnya itu, oleh penulis berasumsi pada ketetapan yang didasarkan pada nishab uang yaitu sebesar 85 gram emas tersebut.

Tampak betul bagaimana Yusuf Qardhawi sebagai salah seorang ulama kontemporer telah berusaha semaksimal mungkin untuk membuat keputusan hukum (ijtihad) terhadap persoalan ini. Pandangan seorang ulama terhadap sebuah kasus itu bisa berbeda dengan pandangan ulama lainnya sehingga oleh Ibnu Hazm menganggap para ulama hanya menduga-duga. ${ }^{14} \mathrm{Hal}$ ini menjadi sesuatu yang lumrah terjadi mengingat persoalan zakat profesi adalah masalah baru di era kontemporer dewasa ini dan tidak ditemukan penjelasannya secara rinci dalam sumber hukum kita, yang dalam hal ini al-Qur'an dan al-Hadis.

Di sinilah letak pembenaran sebuah teori dalam filsafat ilmu, bahwa kebenaran itu adalah relatif, apa yang dianggap benar oleh seseorang itu belum tentu benar bagi orang lain. Demikian pula apa yang di anggap benar kemarin belum tentu benar hari ini, dan apa yang dianggap benar hari ini belum tentu benar di hari esok. Akhirnya kita harus mengakui bahwa kebenaran yang hakiki hanya ada dalam al-Qur'an. Namun ketika sudah dalam bentuk

\footnotetext{
${ }^{13}$ lbid.

${ }^{14}$ /bid. h. 475.
} 
pemahaman seseorang, kebenaran itu tidak mutlak lagi tapi sudah dalam bentuk interpretasi yang bisa terbantahkan oleh orang lain.

\section{Undang-Undang}

zakat adalah merupakan persoalan yang sangat krusial dan membutuhkan aturan yang tegas, sehingga oleh pemerintah menuangkannya dalam sebuah perundang-undangan, yaitu Undang-Undang no. 38 tahun 1999 tentang Pengelolaan Zakat yang terdiri atas 10 bab, 25 pasal dan 35 ayat.

Meskipun UU pengelolaan zakat ini tidak mengatur secara khusus mengenai persoalan zakat profesi, namun dalam salah satu babnya, yaitu pada bab IV pasal 11 ayat 2, tertuang mengenai jenis-jenis harta yang dikenai zakat, dan salah satu jenis diantaranya adalah hasil pendapatan dan jasa. ${ }^{15}$

Sehingga secara tidak langsung persoalan zakat profesi sudah mempunyai aturan yang kuat dan mengikat untuk diperpegangi. Sebagaimana diketahui bersama bahwa meskipun zakat profesi sudah diatur secara khusus dalam Fatwa Majelis Ulama, namun persoalannya kemudian bahwa fatwa merupakan produk pemikiran hukum Islam yang bersifat kasuistik dan tidak mengikat bagi umat muslim secara umum, namun hanya mengikat bagi pihak yang meminta fatwa tersebut.

Hal yang sangat disayangkan adalah disebabkan karena dari keseluruhan isi UU tersebut tidak ada pasal yang membicarakan mengenai sanksi bagi pihak yang tidak mengeluarkan zakat, sebagaimana yang diatur dalam UU Perpajakan. Namun sanksi tersebut hanyalah diperuntukkan bagi Badan atau Lembaga yang mengelola zakat.

Dengan demikian, sangatlah memungkinkan jika kemudian persoalan zakat, dan zakat profesi secara khusus, kurang mencapai tujuan yang dicita-citakan yaitu untuk membantu meningkatkan kesejahteraan masyarakat secara luas. Meskipun sudah ada aturan yang secara khusus mengaturnya.

Meskipun demikian, pandangan tersebut di atas tidak berlaku secara mutlak, sebab tidak sedikit pihak yang berupaya untuk menerapkan zakat profesi sebagai upaya untuk mengatasi persoalan kemiskinan di daerahnya. ${ }^{16}$

\footnotetext{
${ }^{15}$ Kanwil Departemen Agama Prop. Sul-Sel, Undang-Undang RI no. 38 tahun 1999 tentang Pengelolaan Zakat (Ujungpandang: 1999), h. 7.

${ }^{16}$ Contoh yang patut ditiru datang dari Camat Karangampel Teguh Budiarso SSos MSi., Kabupaten Indramayu, yang mencoba memaksimalkan zakat profesi dan mendapat respons positif dari para PNS. Hal ini bisa dilihat dari jumlah zaprof yang terkumpul yang terus mengalami peningkatan baik di tingkat kabupaten maupun kecamatan. Di Kecamatan Karangampel misalnya, zaprof yang terkumpul selama tahun 2008 mencapai Rp145 juta dan telah diberdayakan untuk membantu rehab rumah warga miskin. Selain itu juga untuk membantu siswa-siswi dari keluarga miskin dari berbagai tingkatan. Lihat: Bentuk- yayasan- gempur- Gakin- hingga- zakat- profesi,
} 
Namun, yang harus diakui bahwa persoalan zakat masih sangat jauh dari yang diharapkan, dengan melihat masih tingginya angka kemiskinan di berbagai daerah.

Sehingga, akhirnya pemakalah ingin mengatakan bahwa setidaknya ada 5 hal yang memungkinkan zakat terlebih lagi dengan zakat profesi secara khusus tidak terlaksana dengan maksimal:

1) Kurang kesadaran dan menganggap hanya sebagai ibadah ubudiyah

2) Regulasi / Undang-Undang zakat yang tidak berjalan efektif

3) Pemahaman yang kaku terhadap perubahan

4) Kurang percaya dengan pengelola zakat

5) Kultur / budaya masyarakat yang enggan untuk bershedeqah

\section{PENUTUP}

Berdasarkan pembahasan di atas, dapat disimpulkan bahwa:

1. Zakat profesi adalah merupakan persoalan kontemporer yang membutuhkan pemikiran yang serius untuk bisa menetapkan dasar hukumnya. Dikatakan kontemporer, sebab persoalan tersebut tidak terdapat aturan hukumnya dalam kitab-kitab fikih klasik. Dimana pada zaman Rasulullah saw. beserta ulamaulama salaf belum dianggap perlu untuk memberlakukan zakat profesi disebabkan karena profesi-profesi yang ada pada waktu itu baru sebatas bertani, beternak dan berdagang yang pengaturannya tentang zakat sudah ada dalam kitab-kitab fikih klasik . Namun saat ini, Profesi yang ada itu semakin beragam dan bisa menghasilkan pendapatan yang puluhan kali lebih besar dibandingkan dengan profesi sebagai seorang petani, peternak dan pedagang.

2. Hukum Islam di Indonesia merespon dengan baik persoalan zakat profesi tersebut. Hal ini dibuktikan dengan lahirnya fatwa ulama yang dalam hal ini Majelis Ulama Indonesia (MUI) mengenai wajibnya untuk mengeluarkan zakat profesi. Di samping itu, terbentuknya UU no 38 tahun 1999 tentang pengelolaan zakat yang mendahului lahirnya fatwa wajib zakat profesi, serta pembahasan fikih ala Yusuf Qardhawi meskipun dibantah oleh ulama lainnya.

dalam http://www.radarcirebon.com/index.php/2009031211/061/Radar-Indramayu/Bentukyayasan-gempur-Gakin-hingga-zakat-profesi.html, diakses tanggal 12 April 2009. 


\section{DAFTAR PUSTAKA}

Abdullah, Syarifuddin, Zakat Profesi, Jakarta: PT. Mayo Segoro, 2003.

Al-Jauziyyah, Ibn Qayyim, I'lam al-Muwaqi'in 'an Rabb al- ' ${ }^{2} a m^{3} n$, Juz III, Beirut: Dar al-Jail, t.th.

Departemen Agama RI, Himpunan Fatwa MUI (Jakarta: DIRJEN BIMAS Islam \& Penyelenggaraan Haji DEPAG RI, 2003.

Fowler, HW.,dan F.G. Fowler, The Concise Oxford Dictionary of Current English, London, Oxford, 1952.

Panduan Zakat Profesi, dalam http://www.pkpu.or.id/Panduan.php?id=3

Pandanga Yusuf Qardawi mengenai Zakat Profesi, dalam http://media.isnet.org/islam/Qardhawi/Zakat/Profesi/01.html\#Pandan gan

Zakat

$$
\text { Profesi }
$$

Wajib

atau

Tidak?,

dalam http:///naqshabandibatam.org/keagamaan/artikel/message-dan tulisanIslam/zakat-profesi-wajib-atau-tidak-.html

Seputar Zakat Profesi, dalam http://www. pesantren virtual.com/index.php/seputar-zakat/1180-zakat-profesi.

Zakat profesi, Adakah?, dalam http://aliph.wordpress.com/2007/02/08/zakat-profesi-adakah/

Yayasan Gempur Gakin Hingga Zakat Profesi, dalam http://www.radarcirebon.com/index.php/2009031211/061/RadarIndramayu/Bentuk-yayasan-gempur-Gakin-hingga-zakat-profesi.html

Hooker, MB., Islam Mazhab Indonesia: Fatwa-Fatwa dan Perubahan Sosial, Jakarta: Terju, 2002.

Kanwil Departemen Agama Prop. Sul-Sel, Undang-Undang RI no. 38 tahun 1999 tentang Pengelolaan Zakat (Ujungpandang: 1999), h. 7.

Rofiq, Ahmad, Hukum Islam di Indonesia, cet. II , Jakarta: Rajawali Press, 2007.

Qardhawi,Yusuf, al-Ibadah fi al-Islam, t.t., t.p., 1993, Fiqh az-Zakat, diterjemahkan oleh Salman Harun, Didi Hafidhuddin, dan Hasanuddin, dalam Hukum zakat: Studi Komparatif Mengenai Status dan filsafat Zakat Berdasarkan Qur'an dan Hadis, cet. IV, Jakarta: Mizan, 1996. 